\title{
Elevated bronchoalveolar concentrations of MCP-1 in patients with pulmonary alveolar proteinosis
}

\author{
K. Iyonaga, M. Suga, T. Yamamoto, H. Ichiyasu, H. Miyakawa, M. Ando
}

\begin{abstract}
Elevated bronchoalveolar concentrations of $M C P-1$ in patients with pulmonary alveolar proteinosis. K. Iyonaga, M. Suga, T. Yamamoto, H. Ichiyasu, H. Miyakawa, M. Ando. (C) ERS Journals Ltd 1999.

ABSTRACT: Pulmonary alveolar proteinosis (PAP) is a rare disease of unknown aetiology characterized by accumulations of lipoproteinaceous material within the alveoli. The alveolar macrophages become increasingly foamy, and are thought to have a role in the pathogenesis of PAP. However, the mechanisms of macrophage recruitment are unclear.

In the bronchoalveolar lavage fluid (BALF) of four patients with PAP and 20 normal control subjects, the following were examined: the monocyte chemotactic activity due to the chemokine monocyte chemoattractant protein (MCP)-1 with the use of a chemotactic chamber assay, the levels of MCP-1 by enzyme-linked immunosorbent assay, and the MCP-1 expression on lavage cells by immunocytochemistry and in situ hybridization.

The monocyte chemotactic activity in the BALF of the PAP patients was markedly elevated, and the activity was completely absorbed by treatment with anti-MCP-1. The MCP-1 levels in the BALF were surprisingly high in the PAP group $(25,100 \pm 472$ $\mathrm{pg} \cdot \mathrm{mL}^{-1}$ ), whereas low levels of MCP-1 were detected in the normal control subjects (mean: never smokers 4.8; smokers $10.4 \mathrm{pg} \cdot \mathrm{mL}^{-1}$ ). MCP-1 protein and messenger ribonucleic acid were expressed by macrophages from the PAP patients, and the expression was reduced according to foaming of the cells; there were monocyte-like macrophages with strong expression, small foamy cells with moderate expression, large foamy cells with a faint expression of MCP-1, and ghost cells with no expression. However, the increase of macrophage number in the PAP BALF was relatively small.

These data suggest that monocyte chemoattractant protein $^{-1}$ expression by alveolar macrophages represents an amplification mechanism for the recruitment of additional macrophages to the alveoli in pulmonary alveolar proteinosis. It is possible that an ingestion of an excess of alveolar materials in pulmonary alveolar proteinosis may impair the macrophage function and the survival, resulting in the lack of a prominent increase in the macrophage number in bronchoalveolar lavage fluid.

Eur Respir J 1999; 14: 383-389.
\end{abstract}

First Dept of Internal Medicine, Kumamoto University School of Medicine, Honjo 1-1-1, Kumamoto 860-0816, Japan

Correspondence: M. Suga

First Dept of Internal Medicine

Kumamoto University School of Medicine 1-1-1 Honjo, Kumamoto 860-0811

Japan

Fax: 81963710582

Keywords: Bronchoalveolar lavage fluid foamy macrophages

monocyte chemoattractant protein-1 pulmonary alveolar proteinosis

Received: July 141998

Accepted after revision April 71999

This work was supported in part by a grant in aid for interstitial lung diseases from the Ministry of Health and Welfare, Japan.

Pulmonary alveolar proteinosis (PAP) is a rare disease of unknown aetiology characterized by the accumulation of large amounts of surfactant-rich lipoproteinaceous material within the alveoli $[1,2]$. The majority of cases are considered to be idiopathic, although some cases result from exposure to dust or from an immunological disturbance due to immunodeficiency, haematological or lymphatic malignancies, or chemotherapy [2]. The pathogenesis of this disease is poorly understood; however, one possible mechanism for the alveolar accumulation of surfactant is a decreased clearance from the alveoli, a defect which may be located in the type II cells, which are the sites of synthesis, storage, secretion, and re-uptake of surfactant, or in other cell types such as alveolar macrophages, which are thought to contribute to the terminal catabolism of 10 $20 \%$ of secreted surfactant [3]. In lung specimens from PAP patients, the alveoli have been observed to be filled with periodic acid-Schiff (PAS)-positive material along with infiltrated macrophages and lymphocytes. The macrophages become increasingly foamy and laden with lipids and surfactant proteins. ClaypoOL et al. [4] have suggested that alveolar macrophages in PAP are defective in the processing and clearing of surfactant. It was recently shown that granulocyte-macrophage colony-stimulating factor (GM-CSF)-deficient mice develop alveolar accumulations of surfactant substances similar to that seen in PAP [5-7]. In light of the findings of these studies, macrophages may play an important role in the pathogenesis of PAP, and the absence of macrophage activation for surfactant clearance by locally synthesized GM-CSF could be the mechanism involved. However, the mechanism underlying the local recruitment of the monocyte/ macrophage population is still unclear.

Monocyte chemoattractant protein-1 (MCP-1) belongs to the chemokine supergene family, and is known to be one of the most important mediators of monocyte infiltration in the monocyte/macrophage-mediated inflammatory process [8-12]. MCP-1 was also shown to be chemotactic for T-lymphocytes in vitro [13]. It was hypothesized that MCP-1 may play a role in the macrophage recruitment in PAP. To investigate the mechanism(s) of monocyte/macrophage recruitment from the peripheral vascular spaces to the alveoli in PAP, the monocyte chemotactic activity and the role of MCP-1 in the bronchoalveolar lavage fluid 
(BALF) from PAP patients were studied. The expression of MCP-1 by lavage cells was also analyzed. This study is the first to demonstrate the possibility that MCP-1 may play a role in the regulation of the monocyte/macrophage population in the alveoli of PAP patients.

\section{Materials and methods}

\section{Study population}

Four patients with PAP, three male and one female, were examined in this study. Their median age was 46 yrs (range 36-52 yrs). Three patients were exsmokers, who had ceased smoking $>6$ months before the study, and the other patient was a never-smoker. All patients complained of cough and dyspnoea on exertion, and showed bilateral alveolar-interstitial infiltrates on the chest radiograph. The diagnosis of PAP had been made based on transbronchial lung biopsy and bronchoalveolar lavage (BAL). BAL was performed as a part of the diagnostic examinations, and none of the patients had undergone therapeutic lavage before this study. All were diagnosed as having primary PAP, since they had no history indicating secondary PAP. Twenty healthy normal control subjects were also examined, including 10 smokers (mean age 26.3 yrs, range 22-32) and 10 never-smokers (mean age 25.3 yrs, range $20-32$ ).

The study was approved by the institutional ethical committee on human research, and appropriate informed consent was obtained from each of the patients and control subjects.

\section{Bronchoalveolar lavage}

Diagnostic BAL was performed under local anaesthesia with $2 \%$ lidocaine. A fibreoptic bronchoscope was gently wedged into the segmental bronchus of the middle lobe of the right lung. Fifty millilitres of sterile $0.9 \%$ saline was instilled and recovered by gentle hand suction, for a total of three times (a total of $150 \mathrm{~mL}$ saline). Mucus was removed from the fluid by filtration with two sheets of gauze. The BALF was centrifuged at $400 \times g$ for $10 \mathrm{~min}$ at $4^{\circ} \mathrm{C}$ to separate the cells from the cell-free fluid. The cell-free lavage fluid was stored at $-80^{\circ} \mathrm{C}$ until further analysis. Subsequent measurements of MCP-1 in the BALF demonstrated no decrease in concentration. However, since repeated freezing and thawing may lead to a loss of the biological activity of MCP-1, these procedures were avoided. The number of cells in the BALF was determined by a haemocytometer (Burker-Turk deep 1/10 mm; Erma, Tokyo, Japan). Cell differentials were determined by Giemsa staining of 500 cells prepared by cytocentrifugation (Cytospin-2; Shandon Instruments, Sewickey, PA, USA). The cell numbers and differentials are expressed as mean \pm SEM. The recovery rates of BALF were not significantly different between the PAP (60.3\%) and control (64.2\%) groups.

\section{Immunocytochemistry and cytochemistry}

Immunostaining was performed as described previously [12]. To evaluate MCP-1 expression and ingestion of surfactant material by lavage cells, a well characterized anti-human MCP-1 mouse monoclonal antibody (mAb), F9 [14], and an anti-human surfactant apoprotein A (SP-A) mouse mAb, PE-10 (DAKO Japan, Kyoto, Japan), were employed. In brief, the slides prepared by the cytospin were pretreated with $5 \mathrm{mM}$ periodate for $10 \mathrm{~min}$, washed with phosphate-buffered saline (PBS), and immersed in 3 $\mathrm{mM}$ sodium borohydride for $30 \mathrm{~min}$ to inhibit endogenous peroxidase activity. They were incubated with F9 or PE-10 as the primary antibody for $1 \mathrm{~h}$, washed with PBS, and then incubated with sheep anti-mouse $F\left(a^{\prime}\right)_{2}$ conjugated with peroxidase (Amersham, Amersham, UK) as the secondary antibody for $1 \mathrm{~h}$. For the visualization of peroxidase activity, the slides were incubated with 3,3'diaminobenzidine (Sigma, St. Louis, MO, USA) as a substrate at room temperature for $5 \mathrm{~min}$. Counter-staining was performed with haematoxylin. As a control, non-immunized mouse serum or PBS were used instead of primary antibody, and then processed by the same procedure described above. Oil red $\mathrm{O}$ and PAS staining were also performed to evaluate the ingestion of lipoproteinaceous material by macrophages.

\section{In situ hybridization}

Digoxigenin-labeled single-strand ribonucleic acid (RNA) probes were prepared using a digoxin (DIG) RNA labelling kit (Boehringer Mannheim, Mannheim, Germany) according to the manufacturer's instructions. For a human MCP-1 probe, full-length human MCP-1 complementary deoxyribonucleic acid (DNA) was kindly supplied by T. Yoshimura (National Cancer Institute, Frederick, MD, USA). Hybridization was performed as follows. The lavage cells prepared on the slide by cytocentrifugation were fixed with $4 \%$ paraformaldehyde in $0.1 \mathrm{M}$ phosphate buffer for $20 \mathrm{~min}$, treated with $0.2 \mathrm{~N} \mathrm{HCl}$, and acetylated with $0.25 \%$ acetic anhydride in $0.1 \mathrm{M}$ triethanolamine $(\mathrm{pH} \mathrm{8.0)}$ for $10 \mathrm{~min}$. The slides were dehydrated with a graded series of ethanol, dried in air and then hybridized with digoxigenin-labelled anti-MCP-1 sense or anti-sense probes in $50 \mu \mathrm{L}$ of hybridization solution $(50 \%$ formamide, $10 \mathrm{mM}$ tris-hydroxymethyl-amino methane (Tris)-HCl pH 7.6, $200 \mu \mathrm{g} \cdot \mathrm{mL}$ transfer RNA, $1 \times$ Denhardt's solution, $10 \%$ dextran sulphate, $600 \mathrm{mM} \mathrm{NaCl}$, $0.25 \%$ sodium dodecyl sulphate (SDS) and $1 \mathrm{mM}$ ethylenediamine tetraacetic acid (EDTA)) at $50^{\circ} \mathrm{C}$ for $16 \mathrm{~h}$ in a moisture chamber. After hybridization, the slides were washed briefly in $5 \times$ standard saline citrate (SSC; $1 \times$ SSC: $0.15 \mathrm{M} \mathrm{NaCl}, 0.015 \mathrm{M}$ sodium citrate) and in $50 \%$ formamide, with $2 \times \mathrm{SSC}$ at $50^{\circ} \mathrm{C}$ for $30 \mathrm{~min}$. Ribonuclease (RNase) A treatment $\left(10 \mu \mathrm{g} \cdot \mathrm{mL}^{-1}\right)$ was carried out at $37^{\circ} \mathrm{C}$ for $30 \mathrm{~min}$. The sections were washed with $2 \times \mathrm{SSC}$ and $0.2 \times \mathrm{SSC}$ twice at $50^{\circ} \mathrm{C}$ for $15 \mathrm{~min}$. Hybridized digoxigenin-labelled probes were detected with the use of a nucleic acid detection kit (Boehringer Mannheim). After the colour reaction, the slides were rinsed with $10 \mathrm{mM}$ Tris- $\mathrm{HCl}(\mathrm{pH} 8.0)$ and $1 \mathrm{mM}$ EDTA and then stained with haematoxylin for nuclei. Controls included: 1) hybridization with the sense (messenger ribonucleic acid (mRNA)) probe; 2) RNase A treatment $\left(20 \mu \mathrm{g} \cdot \mathrm{mL}^{-1}\right.$ in $50 \mathrm{mM}$ Tris$\mathrm{HCl}$ ) before hybridization; and 3 ) use of neither the antisense RNA probe nor the anti-digoxigenin antibody. All three control experiments showed no positive signals.

Quantification of monocyte chemoattractant protein-1 levels in bronchoalveolar lavage fluid

The MCP-1 level in the BALF was measured by a sandwich enzyme-linked immunosorbent assay (ELISA) 
as previously described [14, 15]. A well-characterized antihuman MCP-1 mAb and an anti-human rabbit polyclonal antibody were employed [14]. Briefly, a microtitre plate (Nunc, Roskilde, Denmark) was coated with anti-MCP-1 $\mathrm{mAb}$ in coating buffer $\left(0.015 \mathrm{M} \mathrm{Na}_{2} \mathrm{CO}_{3}, 0.035 \mathrm{M}\right.$ $\left.\mathrm{NaHCO}_{3}, 0.003 \mathrm{M} \mathrm{NaN}_{3}, \mathrm{pH} 9.6\right)$ at $4{ }^{\circ} \mathrm{C}$ overnight. After the well contents were shaken out, $300 \mathrm{~mL}$ of $0.2 \%$ bovine serum albumin (Sigma) in coating buffer was added and the plate was incubated at $37^{\circ} \mathrm{C}$ for $30 \mathrm{~min}$. Recombinant human MCP-1 (rhMCP-1) at concentrations ranging $10-20,000 \mathrm{pg} \cdot \mathrm{mL}^{-1}$ and a serial dilution of samples in a washing buffer $(0.05 \mathrm{M}$ Tris-base, $0.15 \mathrm{M} \mathrm{NaCl}$, $0.05 \%$ Tween-20, $\mathrm{pH} 7.5)$ were then applied. The plate was incubated at $37^{\circ} \mathrm{C}$ for $90 \mathrm{~min}$. After the wells were washed three times with $200 \mu \mathrm{L}$ of washing buffer, $100 \mu \mathrm{L}$ of the anti-MCP-1 polyclonal antibody diluted 1:1,000 in washing buffer was added, and the plate incubated at $37^{\circ} \mathrm{C}$ for $90 \mathrm{~min}$. After washing, $100 \mu \mathrm{L}$ of peroxidaseconjugated donkey anti-rabbit $\mathrm{F}\left(\mathrm{ab}^{\prime}\right)_{2}$ (Amersham) diluted 1:1000 in the washing buffer was added and the plate incubated at room temperature for $60 \mathrm{~min}$. The wells were washed three times with $0.05 \mathrm{M}$ Tris-buffered saline, reacted with $100 \mu \mathrm{L}$ of $2,2^{\prime}$-azinobis (3'-ethylbenzthiazoline) sulfonic acid (KPL Inc., Gaithersburg, MD, USA), and read spectrophotometrically at $405 \mathrm{~nm}$. The sensitivity limit of the assay was $39 \mathrm{pg} \cdot \mathrm{mL}^{-1}$, and the MCP-1 was not detected in the BALF of control subjects. BALF from control subjects was concentrated tenfold by centrifugal concentrators (Centricon-3; Grace Japan KK, Amicon, Tokyo, Japan) with a 3,000 molecular weight cut-off membrane, then stored at $-70 \mathrm{C}$ until the assay. Data for different groups are presented as means \pm SEM.

\section{Chemotaxis assays}

The monocyte chemotactic activity in the BALF was assessed. Human peripheral blood monocytes were separated from the blood of healthy volunteers by a two-step method utilizing Ficoll-Hypaque (Pharmacia, Uppsala, Sweden) and a discontinuous Percoll gradient (Pharmacia) [16]. The purity of monocytes ranged $90-95 \%$ of the cells by differential counts with Giemsa staining. Cell viability was assessed with trypan blue and was $>95 \%$. Chemotaxis was conducted in 48-well microchemotaxis chambers (Neuro Probe, Cabin John, MD, USA). Purified monocyte suspensions in Roswell Park Memorial Institute $(\mathrm{RPMI}) 1640$ media $\left(1 \times 10^{6}\right.$ cells $\left.\cdot \mathrm{mL}^{-1}\right)$ were added to the top of the chamber and permitted to migrate down through a $5-\mu \mathrm{m}$-porosity polycarbonate membrane $(\mathrm{Nu}-$ cleopore, Pleasanton, CA, USA) towards the bottom chamber. Monocytes were incubated for $1.5 \mathrm{~h}$ at $37^{\circ} \mathrm{C}$ in humidified air with $5 \% \mathrm{CO}_{2}$.

After incubation, the membrane was removed, nonmigrating cells were wiped off, and the filter was fixed for 5 min in absolute methanol. The filter was then air-dried and stained with Diff Quik (Kokusaishiyaku, Kobe, Japan). The numbers of migrated cells were counted in four random high-power fields. The chemotactic activity is expressed as the mean \pm SD of the migrated monocyte numbers in four high-power fields. All samples was assayed in triplicate and the assay conducted three times.

In each assay, rhMCP-1 (20 ng. $\mathrm{mL}^{-1}$ in RPMI 1640) and RPMI 1640 were employed as the positive and negative controls, respectively. To test for the neutralization of chemotaxis in each BALF sample by anti-MCP-1, $100 \mu \mathrm{L}$ of each sample was preincubated with $10 \mu \mathrm{L}$ of anti-human MCP-1 mouse mAb (E11) [14] or an equivalent concentration of control mouse immunoglobulin (Ig)G (Amersham) for $1 \mathrm{~h}$ at $37^{\circ} \mathrm{C}$. The samples were then tested for monocyte chemotactic activity. This addition of antiMCP-1 completely neutralized the chemotaxis to rhMCP-1 $\left(20 \mathrm{ng} \cdot \mathrm{mL}^{-1}\right)$ to the background migration level observed with the medium. The addition of anti-MCP-1 to the medium did not affect the background migration level.

\section{Statistical analysis}

The BALF analysis data and MCP-1 levels are reported as mean \pm SEM. Comparisons between PAP patients and control subjects were made using the nonparametric MannWhitney test. In the chemotactic assays, the data are expressed as mean $\pm \mathrm{SD}$, and comparisons were made by using the unpaired Student's t-test. Differences were considered significant at $\mathrm{p}$-values $<0.05$.

\section{Results}

\section{Cell analysis of bronchoalveolar lavage fluid}

Transbronchial lung biopsy specimens of PAP revealed that the alveoli were filled with fine-granular eosinophilic material, and the alveolar septa showed only slight reactive thickening with type II cell hyperplasia (haematoxylineosin). In the alveoli, foamy macrophages and mononuclear cells had infiltrated.

The general characteristics of the BALF are summarized in table 1. In the PAP patients, the total cell number

Table 1. - Monocyte chemoattractant protein (MCP)-1 concentration and analysis of bronchoalveolar lavage fluid

\begin{tabular}{|c|c|c|c|c|c|c|c|c|c|}
\hline & \multirow{2}{*}{ Sex } & \multirow{2}{*}{$\begin{array}{l}\text { Age } \\
\text { yrs }\end{array}$} & \multirow{2}{*}{$\begin{array}{l}\text { Smoking } \\
\text { status }\end{array}$} & \multirow{2}{*}{$\begin{array}{l}\mathrm{MCP}-1 \\
\mathrm{pg} \cdot \mathrm{mL}^{-1}\end{array}$} & \multirow{2}{*}{$\begin{array}{c}\text { Total cells } \\
\times 10^{3} \text { cells } \cdot \mathrm{mL}^{-1}\end{array}$} & \multirow{2}{*}{$\begin{array}{c}\text { Recovery } \\
\%\end{array}$} & \multicolumn{3}{|c|}{ Cell differentials \% } \\
\hline & & & & & & & $\mathrm{AM}$ & LYM & $\mathrm{PMN}$ \\
\hline PAP patient $(n=4)$ & & & & $25100 \pm 472^{*}$ & $127.3 \pm 12.9^{*}$ & $60.3 \pm 3.6$ & $51.0 \pm 4.9^{\ddagger}$ & $46.0 \pm 5.5^{\ddagger}$ & $2.8 \pm 0.2$ \\
\hline 1 & M & 52 & Ex & 38600 & 156.0 & 67.7 & 50.0 & 48.0 & 2.0 \\
\hline 2 & $\mathrm{~F}$ & 36 & Ex & 24400 & 98.0 & 65.0 & 55.0 & 42.0 & 3.0 \\
\hline 3 & M & 44 & Ex & 19700 & 115.0 & 52.5 & 38.0 & 60.0 & 2.0 \\
\hline 4 & $\mathrm{M}$ & 48 & NS & 17800 & 140.0 & 56.0 & 61.0 & 34.0 & 4.0 \\
\hline \multicolumn{10}{|l|}{ Control subjects } \\
\hline Nonsmokers $(\mathrm{n}=10)$ & & & & $4.8 \pm 0.5$ & $72.9 \pm 3.7$ & $66.0 \pm 3.4$ & $91.1 \pm 1.7$ & $8.1 \pm 1.3$ & $1.0 \pm 0.5$ \\
\hline Smokers $(\mathrm{n}=10)$ & & & & $10.4 \pm 0.8^{*}$ & $118.4 \pm 7.1 *$ & $62.9 \pm 2.5$ & $90.3 \pm 0.8$ & $7.7 \pm 0.8$ & $2.2 \pm 0.4$ \\
\hline
\end{tabular}

PAP: pulmonary alveolar proteinosis; AM: alveolar macrophages; LYM: lymphocytes; PMN: polymorphonuclear cells; Smoking status: Ex: exsmoker; NS: never-smoker. Values are expressed as mean \pm SEM. ${ }^{*}: \mathrm{p}<0.01$, compared to normal control never-smokers; ${ }^{*}$ : $\mathrm{p}<0.01$, compared to normal control subjects. 
$\left(127.3 \pm 12.9 \times 10^{3}\right.$ cells $\left.\cdot \mathrm{mL}^{-1}\right)$ in the BALF was signifi-

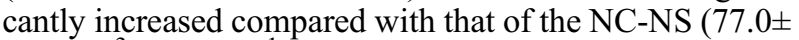
$5.3 \times 10^{3}$ cells $\left.\cdot \mathrm{mL}^{-1}\right)(\mathrm{p}<0.01)$, although the number was not significantly different between the PAP patients and the smoking control subjects $\left(118.4 \pm 7.1 \times 10^{3}\right.$ cells $\left.\cdot \mathrm{mL}^{-1}\right)$. The cell analysis of the PAP BALF revealed a significantly reduced percentage of alveolar macrophages $(51.0 \pm$ $4.9 \%$ ) and a significantly increased percentage of lymphocytes $(46.0 \pm 5.5 \%)$ compared to those of the control group (both $\mathrm{p}<0.01$ ).

In the cytospin preparations of BALF, Giemsa staining showed a variety of alveolar macrophages, i.e., monocytelike macrophages (ranging $18-32 \%$ of macrophages), small foamy macrophages (26-43\%), large foamy macrophages (23-28\%), and ghost cell-like huge cells (13-18\%) (fig. 1a). PAS staining revealed that these alveolar macrophages contained PAS-positive material (fig. 1b). Oil red $\mathrm{O}$ staining showed that foamy macrophages ingested a large amount of lipids, while monocyte-like macrophages ingested only a little (fig. 1c). Furthermore, an immunocytochemical study with the anti-SP-A mAb, PE-10, revealed that these alveolar macrophages ingested surfactant materials (fig. 1d). The results of these cytochemical analyses are summarized in table 2.
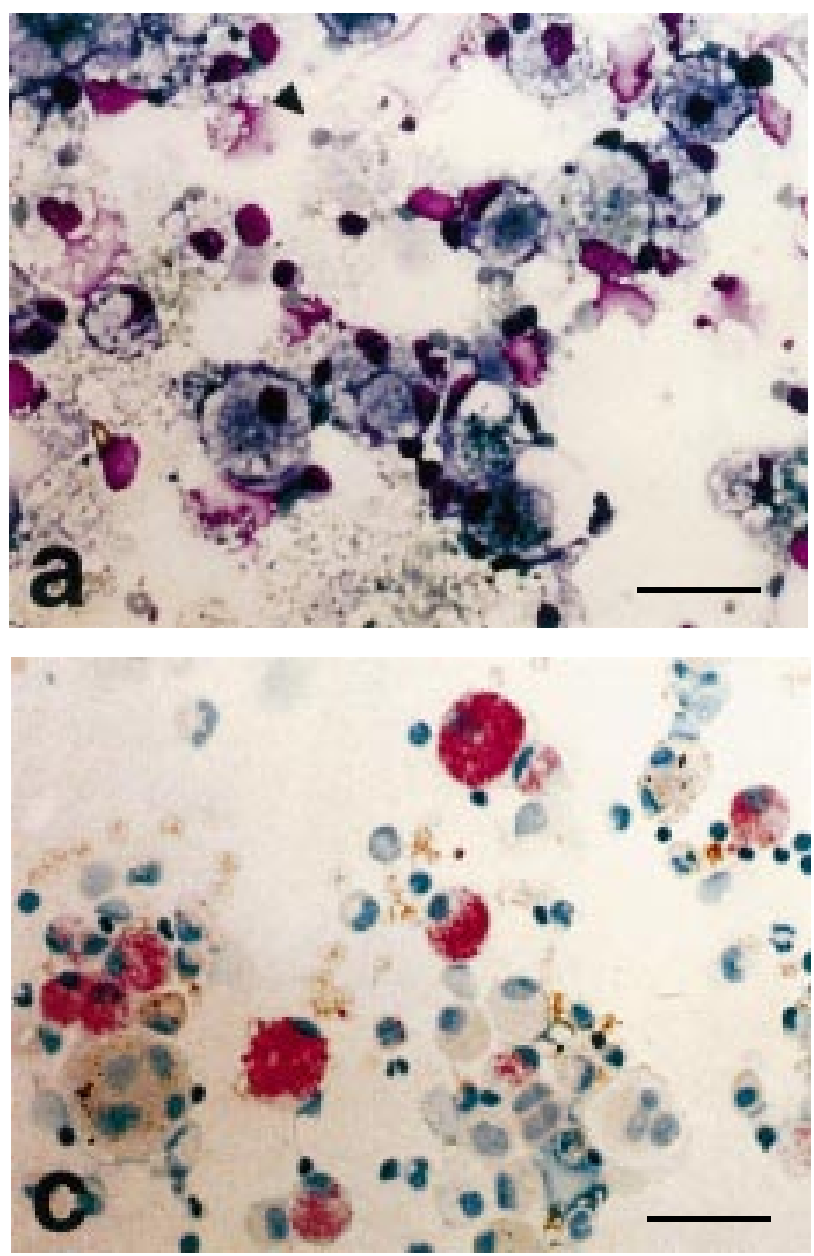

Fig. 1. - Morphology and storage of lipoproteinaceous material in alveolar macrophages from patients with pulmonary alveolar proteinosis (PAP). a) Giemsa staining shows a variety of morphology of alveolar macrophages; monocyte-like small macrophages, foamy macrophages, and ghost cell-like huge cells (arrow head). b) Periodic acid-Schiff (PAS) staining demonstrates alveolar macrophages containing PAS-positive material. c) Oil red O staining reveals that foamy macrophages contained large amounts of lipids although monocyte-like macrophages ingested only a little. d) An immunocytochemical study with anti-surfactant apoprotein A (SP-A) monoclonal antibody, PE-10, shows alveolar macrophages ingesting surfactant material. Results also summarized in table 2. (Internal scale bar=40 $\mu \mathrm{m}$.)
Elevation of monocyte chemoattractant protein-1 levels

The MCP-1 concentrations in the BALF were measured by ELISA. In all 20 control subjects, low levels of MCP-1 were detected (never-smokers $4.8 \pm 0.5 \mathrm{pg} \cdot \mathrm{mL}^{-1}$, smokers $10.4 \pm 0.8 \mathrm{pg} \cdot \mathrm{mL}^{-1}$ ), whereas a marked elevation of MCP-1 was detected in all PAP patients $\left(25,100 \pm 472 \mathrm{pg} \cdot \mathrm{mL}^{-1}\right.$ range $\left.17,800-38,600 \mathrm{pg} \cdot \mathrm{mL}^{-1}\right)$, as summarized in table 1 .

\section{Assessment of monocyte chemotactic activity}

Each BALF sample was assessed for monocyte chemotactic activity. The chemotactic activity is expressed as the mean \pm SD of migrated monocyte cells in four high-power fields. The results are shown in figures 2 and 3. In all four PAP patients, marked monocyte chemotactic activity (about five times as high as that of the control group) was shown, and the activity was significantly higher than that of the control group $(\mathrm{p}<0.01)$. The activity was decreased to the levels of the control group by the serial dilution of the BALF samples (fig. 2).

To examine the effect of MCP-1 on monocyte chemotactic activity in BALF, a neutralization test for each BALF sample was employed using an anti-MCP-1 mAb and a
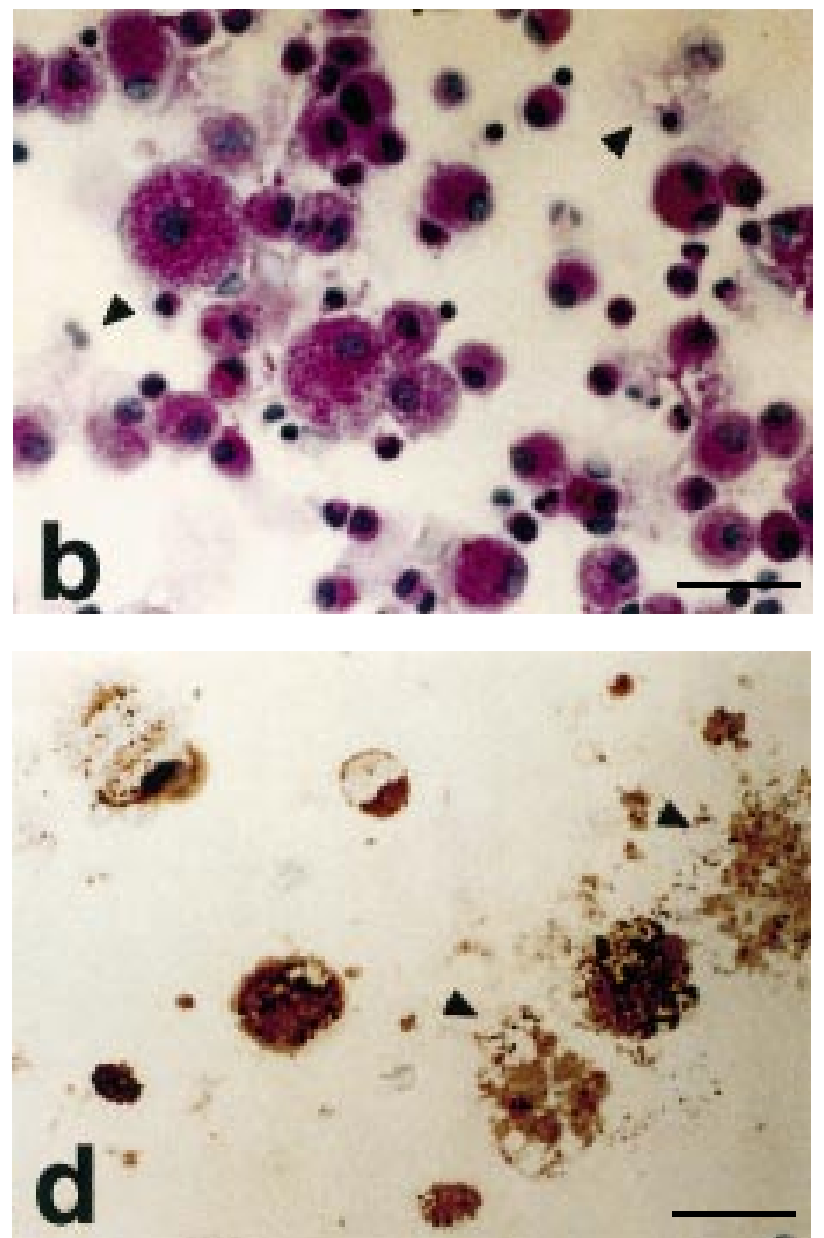
Table 2. - The relationship between morphology and monocyte chemoattractant protein (MCP)-1 expression in alveolar macrophages of pulmonary alveolar proteinosis patients

\begin{tabular}{lcccc}
\hline & $\begin{array}{c}\text { Monocyte- } \\
\text { like }\end{array}$ & $\begin{array}{c}\text { Small } \\
\text { foamy }\end{array}$ & $\begin{array}{c}\text { Large } \\
\text { foamy }\end{array}$ & $\begin{array}{c}\text { Ghost } \\
\text { cell }\end{array}$ \\
\hline MCP-1 expression & ++ & ++ & + & - \\
Oil red O stain & $-/+$ & + & ++ & - \\
PAS stain & ++ & ++ & + & $+/-$ \\
PE-10 & + & ++ & ++ & + \\
\hline
\end{tabular}

MCP-1 expression was evaluated by immunohistochemistry and in situ hybridization, and the storage of lipoproteinaceous material in the cytoplasm was studied by oil red $\mathrm{O}$ staining, periodic acid-Schiff (PAS) staining, and immunocytochemical reactivity with the anti-surfactant apoprotein A monoclonal antibody, PE10. The intensity of the staining results are expressed as -: negative; +: weakly positive; ++: strongly positive.

mouse IgG as a control. The monocyte chemotactic activity in the BALF from the PAP patients was significantly neutralized by the anti-MCP-1 mAb $(p<0.01)$ to the control group level (fig. 3). The preincubation of the sample with control mouse IgG did not affect the monocyte chemotactic activities.

\section{Monocyte chemoattractant protein-1 expression in bron- choalveolar lavage cells}

MCP-1 expression was detected in alveolar macrophages by both in situ hybridization (figs. $4 \mathrm{a}$ and $\mathrm{b}$ ) and immunocytochemistry using an anti-MCP-1 mAb (figs. $4 \mathrm{c}$ and $\mathrm{d}$ ). These analyses revealed that MCP-1 protein and mRNA were expressed intensely by alveolar macrophages, from monocyte-like small macrophages to the small foamy cells. The expression was reduced in accordance with the expansion of the cytoplasm with the foaming of macrophages. The ghost cell-like, huge macrophages showed no MCP-1 expression. The relationship among the MCP-1 expression evaluated by immunocytochemistry and in situ hybridization, the cell morphology, and the results of $\mathrm{PAS}$, oil red $\mathrm{O}$ staining, and immunocytochemistry with PE-10, are summarized in table 2. In normal control subjects, no significant MCP-1 expression was detected by in situ hybridization nor immunocytochemistry (data not shown).

\section{Discussion}

This study demonstrates the existence of MCP-1dependent monocyte chemotactic activity in the BALF from patients with PAP. The MCP-1 is locally expressed by alveolar macrophages, and the expression may be impaired by the storage of an excess of lipoproteinaceous material in the alveoli.

A marked elevation of the MCP-1 level was observed in the BALF from all four patients with PAP, although this study included only a limited number of PAP patients. The increase was $\sim 20$-fold higher compared to patients with idiopathic pulmonary fibrosis (unpublished data) and $~ 300$ fold higher compared with the results from hypersensitivity pneumonitis reported by SugIYAMA et al. [17]. In addition, in vitro chemotactic chamber assay demonstrated the comparable monocyte chemotactic activity in the BALF from PAP patients, which was significantly neutralized by

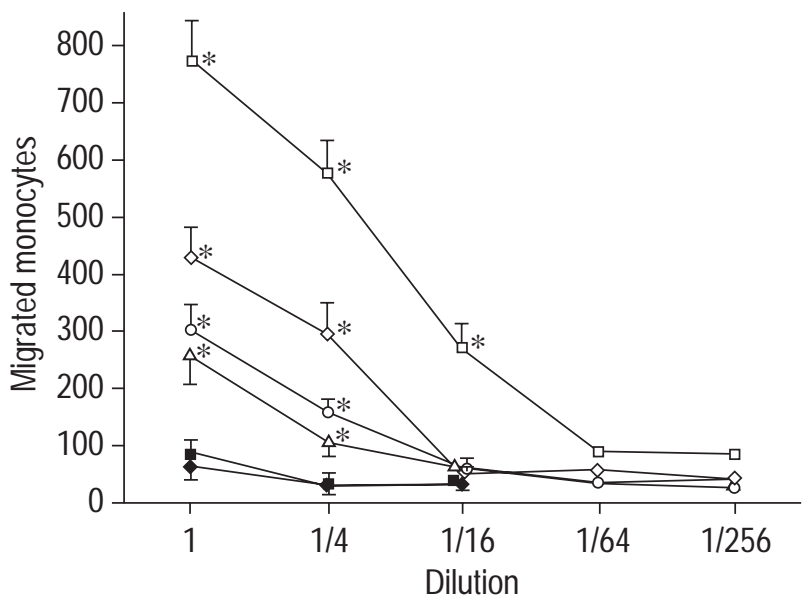

Fig. 2. - Monocyte chemotactic activity in the bronchoalveolar lavage fluid (BALF) of four patients with pulmonary alveolar proteinosis and two control groups. Monocyte chemotactic activity was assessed using Neuro Probe 48-well micro chemotaxis chambers. The number of migrated cells was counted in four random high-power fields. Chemotactic activity is expressed as the mean \pm SD of migrated monocyte cells in four high-power fields. $\square$ : Patient $1 ; \diamond$ : patient 2 ; $\bigcirc$ : patient $3 ; \triangle$ : patient 4 ; $\mathbf{\square}$ : smoking control group; $\diamond$ : never-smoking control group. *: $\mathrm{p}<0.01$ compared to control group.

the anti-MCP-1 mAb. These results suggest that elevated production of MCP-1 occurred in the alveoli of PAP. The high concentration of MCP-1 may represent an amplification mechanism for the recruitment of additional macrophages from the peripheral vascular spaces to the alveoli in PAP. This enhanced recruitment of macrophages may contribute to a more rapid clearance or catabolism of accumulated materials in the alveoli in PAP.

In contrast to the BALF from PAP patients, a very low concentration of MCP-1 was detected in the BALF from $\mathrm{NC} ;\left(4.8 \mathrm{pg} \cdot \mathrm{mL}^{-1}\right.$ in never-smokers and $10.4 \mathrm{pg} \cdot \mathrm{mL}^{-1}$ in smokers), which were consistent with the results of previous studies [18, 19]. A monocyte chemotactic activity was also detected in the BALF from the control subjects;

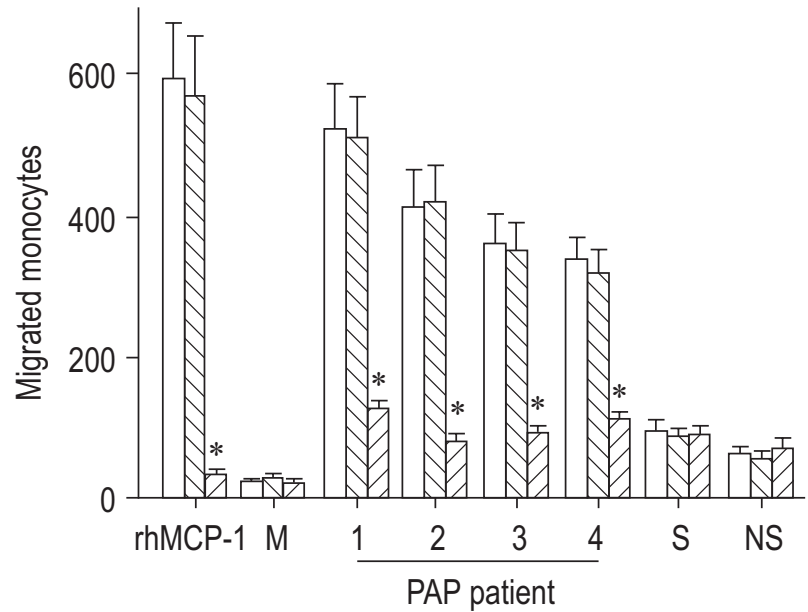

Fig. 3. - Effect of anti-human monocyte chemoattractant protein (rhMCP)-1 monoclonal antibody (mAb) $(\mathbb{Z})$ on monocyte chemotactic activity in the bronchoalveolar lavage fluid (BALF) from pulmonary alveolar proteinosis (PAP) patients compared to mouse immunoglobulin $\mathrm{G}(\mathbb{\mathbb { N }})$ and monocytes alone $(\square)$. Monocyte chemotactic activity was assessed by the procedure described in the Materials and methods. M: medium; S: smoker control group; NS: never-smoker control group. *: $\mathrm{p}<0.01$ compared to control groups. 

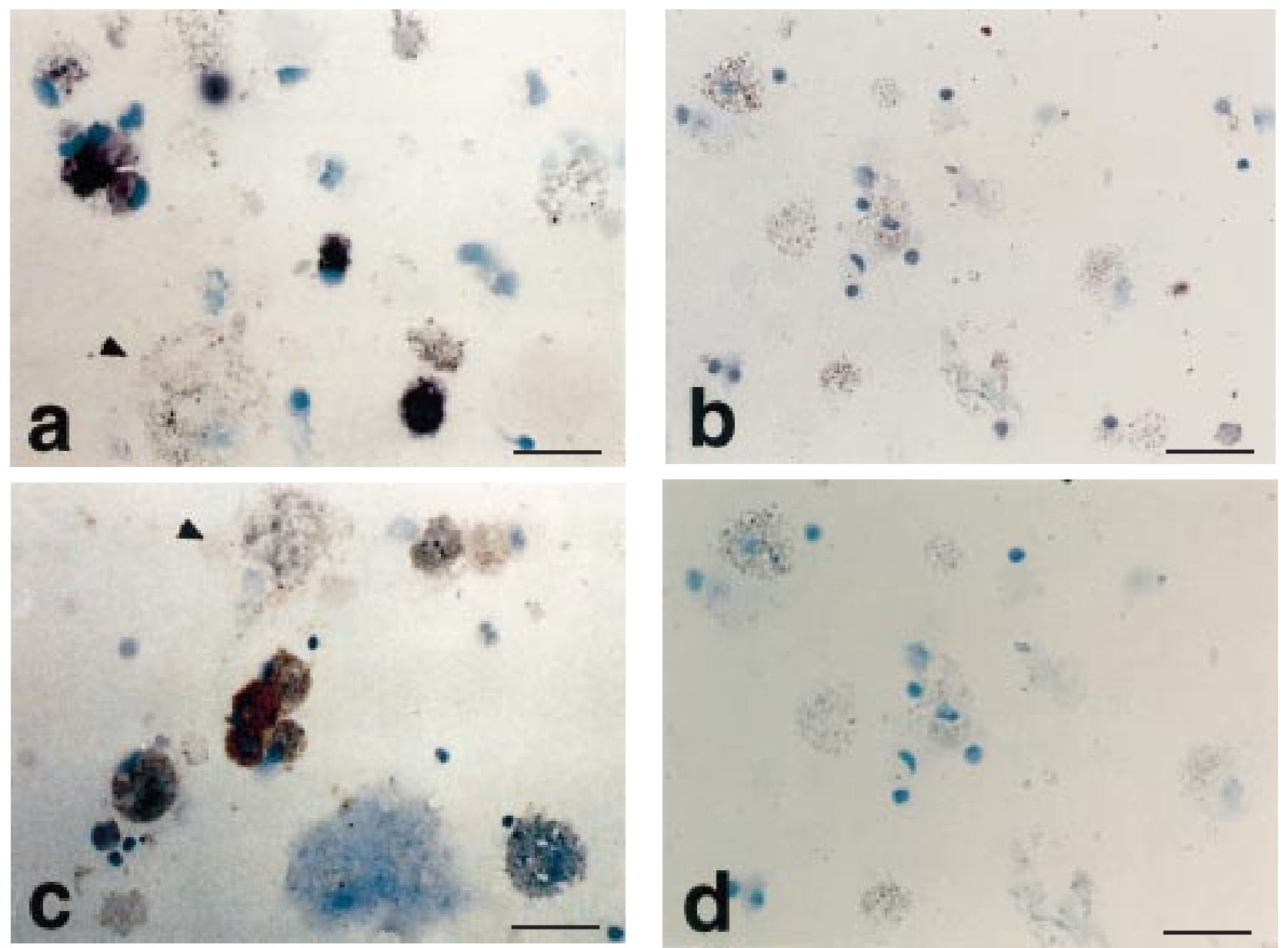

Fig. 4. - Monocyte chemoattractant protein (MCP)-1 expression by alveolar macrophages from patients with pulmonary alveolar proteinosis (PAP). MCP-1 expression was detected in alveolar macrophages by both in situ hybridization (a) with anti-sense probe; (b) with sense probe and immunocytochemistry using an anti-MCP-1 monoclonal antibody (c) and a control mouse immunoglobulin (Ig)G (d). The most intense expression was observed in monocyte-like small macrophages, and the expression was reduced in accordance with the expansion of the cytoplasm, foaming of macrophages. The ghost cell-like huge macrophages show no MCP-1 expression. Control slides, the result from in situ hybridization with sense probe for MCP-1 (b) and from immunohistochemical staining with control mouse IgG (d) showed no significant positive reactions. The results are also summarized in table 2. (Internal scale bar=40 $\mu \mathrm{m}$.)

however, anti-MCP-1 mAb could not neutralize the activity, and no significant MCP-1 expression was detected by in situ hybridization nor immunocytochemistry in this group. It was therefore thought that MCP-1 may play only a small role in the monocyte chemotactic activity in the BALF from control subjects.

It has been reported that MCP-1 was expressed by alveolar macrophages, type II cells, bronchiolar epithelial cells, and smooth muscle cells in a variety of inflammatory lung conditions [9-12]. In those reports, alveolar macrophages were one of the major source of MCP-1. In the present study of PAP, alveolar macrophages that ingested accumulated material in the alveoli were considered a major source of MCP-1, although other cell types may participate in MCP-1 production. This study clearly demonstrated that alveolar macrophages showed various stages of foaming, small monocyte-like macrophages, typical foam cells ingesting oil red O-positive materials, and ghost cells without lipid ingestion. It was of interest that the MCP-1 expression was more intense in the smaller foam cells than in the larger foam cells, and the expression was reduced in accordance with the expansion of the cytoplasm by the excessive foaming. It was report- ed that MCP-1 was expressed by macrophage-derived foam cells in atherosclerotic lesions [20,21], and that the expression of interleukin (IL)-8 and MCP-1 was induced by the cholesterol loading of macrophages [22]. Taken together, these findings suggest that the ingestion of alveolar material may stimulate macrophages to express MCP-1, and that the storage of excess material may lead to the formation of the ghost cells, resulting in a reduced expression of MCP-1.

The BAL analysis of PAP patients demonstrated that the number of alveolar macrophages was increased compared with that of the never-smoker control group, but that the increase was not prominent, only to the level found in the smoker control group. There is a significant discrepancy between the increased monocyte chemotactic activity and the relatively small increase in macrophage number in the BALF from the PAP patients. The reason has not been elucidated in this study. Several studies have shown that the functions of alveolar macrophages in PAP were defective, and that the functional alteration may be acquired after these cells reach the alveoli and is probably related to a massive ingestion of the abnormal alveolar material [23]. Furthermore, the activity of GM-CSF which has 
been considered critical to the maintenance of alveolar macrophage survival and function, including to surfactant catabolism activity, was decreased in PAP [7, 24-26]. It has also been reported that oxidized low-density lipoprotein leads to apoptosis in monocyte/macrophages [27]. Taken together, it was possible that the decreased GM-CSF activity may impair the macrophage catabolic function of ipoproteinaceous material, resulting in the decreased survival of alveolar macrophages. Another explanation for the discrepancy could be that the high concentration of MCP-1 in the BALF may merely reflect the accumulation of the chemotactic protein in the alveoli, and the existence of large amounts of lipoproteinaceous material between the alveoli and the peripheral vascular space may interfere with the MCP-1 activity in vivo.

In summary, this study is the first to demonstrate that monocyte chemoattractant protein-1 was expressed by alveolar macrophages and accumulated in the alveoli at high concentrations in pulmonary alveolar proteinosis patients. The bronchoalveolar lavage fluid from the pulmonary alveolar proteinosis patients showed the elevated monocyte chemotactic activity, most of which was dependent on the activity of monocyte chemoattractant protein-1. However, there is a significant discrepancy between the high elevation of monocyte chemoattractant protein-1 levels and the relatively small increase in macrophage number in the bronchoalveolar lavage fluid of pulmonary alveolar proteinosis patients. It is speculated that the excess alveolar material may impair the survival of alveolar macrophages, resulting in the lack of a prominent increase in macrophage number in the bronchoalveolar lavage fluid.

Acknowledgements. The authors thank M. Takeya (Dept of Pathology in the author's University) and T. Yoshimura (National Cancer Institute, Frederick, MD, USA) for the kind gifts of anti-MCP-1 $\mathrm{mAb}$ and MCP-1 cDNA, respectively.

\section{References}

1. Rosen SH, Castleman B, Liebow AA. Pulmonary alveolar proteinosis. N Engl J Med 1958; 258: 1123-1142.

2. Prakash UB, Barhman SS, Carpenter HA, Dines DE, Marsh HM. Pulmonary alveolar phospholipoproteinosis: experience with 34 cases and a review. Mayo Clin Proc 1987; 62: 499-518.

3. Rider DD, Ikegami M, Jobe AH. Localization of alveolar surfactant clearance in rabbit lung cells. Am J Physiol 1992; 263: L201-209.

4. Claypool WD, Rogers RM, Matuschak GM. Update on the clinical diagnosis, management, and pathogenesis of pulmonary alveolar proteinosis (phospholipidosis). Chest 1984; 85: 550-558.

5. Dranoff G, Crawford AD, Sadelain M, et al. Involvement of granulocyte-macrophage colony-stimulating factor in pulmonary homeostasis. Science 1994; 264: 713-716.

6. Stanley E, Lieschke GJ, Grail D, et al. Granulocyte/macrophage colony-stimulating factor-deficient mice show no major perturbation of hematopoiesis but develop a characteristic pulmonary pathology. Proc Natl Acad Sci USA 1994; 91: 5592-559.

7. Huffman JA, Hull WH, Dranoff G, Mulligan RC, Whisett JA. Pulmonary epithelial cell expression of GM-CSF corrects the alveolar proteinosis in GM-CSF deficient mice. J Clin Invest 1996; 97: 649-655.

8. Oppenheim JJ, Zachariae COC, Mukaida N, Matsushima $K$. Properties of the novel proinflammatory supergene "intercrine" cytokine family. Annu Rev Immunol 1991; 9: 617.
9. Jones ML, Warren JS. Monocyte chemoattractant protein 1 in a rat model of pulmonary granulomatosis. Lab Invest 1992; 66: 498-503.

10. Warren JS, Jones ML, Flory CM. Analysis of monocyte chemoattractant protein 1-mediated lung injury using rat lung organ cultures. Am J Pathol 1993; 143: 894-906.

11. Antoniades HN, Neville-Golden J, Galanopoulos T, Kradin R, Valente A, Graves D. Expression of monocyte chemoattractant protein 1 mRNA in human idiopathic pulmonary fibrosis. Proc Natl Acad Sci USA 1992; 89: 5371-5375.

12. Iyonaga K, Takeya M, Saita N, et al. Monocyte chemoattractant protein-1 in idiopathic pulmonary fibrosis and other interstitial lung diseases. Human Pathol 1994; 25: 455-463.

13. Taub DD, Proost P, Murphy WJ, et al. Monocyte chemotactic protein-1, $-2,-3$ are chemotactic for human $\mathrm{T}$ lymphocytes. J Clin Invest 1995; 95: 1370-1376.

14. Yoshimura T, Takeya M, Takahashi K, Kuratsu J, Leonard EJ. Production and characterization of mouse monoclonal antibodies against human monocyte chemoattractant protein-1. J Immunol 1991; 147: 2229-2233.

15. Iyonaga K, Suga M, Ichiyasu H, Yamamoto T, Hiraga Y, Ando M. Elevation of serum monocyte chemoattractant protein-1 and its clinical application for estimating the activity of granuloma formation in sarcoidosis. Sarcoidosis Vasc Dif 1998; 15: 165-17.

16. Denholm EM, Wolber FM. A simple method for the purification of human peripheral blood monocytes: A substitute for Sepracell-MN. J Immunol Methods 1991; 144: 247-251.

17. Sugiyama Y, Kasahara T, Mukaida N, Matsushima K, Kitamura S. Chemokines in bronchoalveolar lavage fluid in summer-type hypersensitivity pneumonitis. Eur Respir $J$ 1995; 8: 1084-1090.

18. Boitelle A, Gosset P, Copin MC, et al. MCP-1 secretion in lung from nonsmoking patients with coal worker's pneumoconiosis. Eur Respir J 1997; 10: 557-562.

19. Capelli A, Di Stefano A, Lusuardi M, Gnemmi I, Balbi B, Donner CF. Increased MIP-1 $\beta$ and MCP-1 in bronchoalveolar lavage fluid of chronic bronchitic patients. $A m J$ Respir Crit Care Med 1998; 157: A796.

20. Yla-Herttuala S, Lipton BA, Rosenfeld ME, et al. Expression of monocyte chemoattractant protein 1 in macrophage-rich areas of human and rabbit atherosclerotic lesions. Proc Natl Acad Sci USA 1991; 88: 5252-5256.

21. Nelken NA, Coughlin SR, Gordon D, Wilcox JN. Monocyte chemoattractant protein-1 in human atheromatous plaques. J Clin Invest 1991; 88: 1121-1127.

22. Wang N, Tabas I, Winchester R, Ravalli S, Rabbani LE, Tall A. Interleukin 8 is induced by cholesterol loading of macrophages and expressed by macrophages foam cells in human atheroma. J Biol Chem 1996; 271: 8837-8842.

23. Wang BM, Stern EJ, Schmidt RA, Pierson DJ. Diagnosing pulmonary alveolar proteinosis. A review and update. Chest 1997; 111: 460-466.

24. Tchou-Wong KM, Harkin TJ, Chi C, Bodkin M, Rom WN. GM-CSF gene expression is normal but protein release is absent in a patient with pulmonary alveolar proteinosis. Am J Respir Crit Care Med 1997; 156: 1999-2002.

25. Dranoff G, Crawford AD, Sadelain M, et al. Involvement of granulocyte-macrophage colony-stimulating factor in pulmonary homeostasis. Science 1994; 264: 713-716.

26. Blau HS, Riklis S, Kravtsov V, Kalina M. Secretion of cytokines by rat alveolar epithelial cells: possible regulatory role for SP-A. Am J Physiol 1994; 266: 148-155.

27. Hardwick S, Hegyi L, Clare K, et al. Apoptosis in human monocyte-macrophages exposed to oxidized low density lipoprotein. J Pathol 1996; 179: 294-302. 